\title{
Importance of bovine mastitis in Africa
}

Thabiso E. Motaung ${ }^{a *}$, Kiro R. Petrovski ${ }^{b}$, Inge-Marie Petzer ${ }^{c}$, Oriel Thekisoe ${ }^{d}$, Toi J.Tsilo ${ }^{\mathrm{a}, \mathrm{e}}$

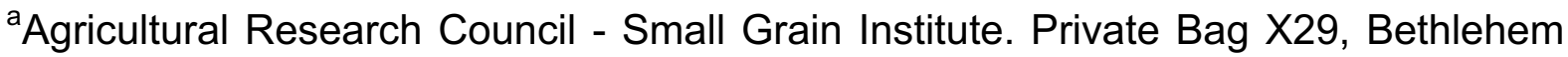
9700, South Africa

${ }^{\mathrm{b}}$ School of Animal and Veterinary Sciences, The University of Adelaide, Roseworthy Campus, JS Davies building G13, Roseworthy 5371, Australia

${ }^{\mathrm{C}}$ Department of Production Animal Studies, Udder Health, Faculty of Veterinary Science, University of Pretoria, Private Bag X04, Onderstepoort 0110, South Africa

dUnit for Environmental Sciences and Management, North-West University, Private Bag X6001, Potchefstroom 2520, South Africa

e Department of Life and Consumer Sciences, University of South Africa, PO Box 392, Pretoria 0003, South Africa

${ }^{*}$ Corresponding author

Agricultural Research Council - Small Grain Institute. Private Bag X29, Bethlehem 9700, South Africa

E-mail address: motaung.thabiso.eric@gmail.com

Running tittle: Bovine mastitis in Africa 


\section{Abstract}

Bovine mastitis is an important animal production disease that affects the dairy industry globally. Studies have estimated the prevalence of this disease in approximately $30 \%$ of African countries, with the highest prevalence found in Ethiopia. This is despite the wide cattle distribution in Africa, and the largest number of dairy farms and herds in countries such as South Africa, Kenya and Uganda. Furthermore, the estimated financial losses due to direct and indirect impacts of bovine mastitis are lacking in this continent. Therefore, intensive research efforts will help determine the continent-wide economic impacts and advance careful monitoring of disease prevalence and epidemiology. Here, published cases supporting the occurrence and importance of bovine mastitis in certain regions of Africa are outlined.

Key words: Africa, economic impact, mastitis, milk production, somatic cell count 


\section{Introduction}

Bovine mastitis places a major economic burden on the dairy industry globally (Bradley, 2002; Wellenberg et al., 2002; Petrovski et al., 2006; Man'ombe, 2012; Carrillo-Casas and Miranda-Morales, 2012), and a major concern for the dairy cattle community in Africa. This disease results due to prokaryotic (bacterial) and eukaryotic (mycotic and algal) species invading the udder tissue and subsequently inflaming the mammary glands (Bradley, 2002). Economic costs associated with bovine mastitis are the result of poor quality and reduced yield of milk (Petrovski et al., 2006; Halasa et al., 2009), that seems to vary with each causative pathogen (Oba, 2005). Direct and indirect losses contribute massively to economic impacts of the disease. Direct losses result from milk wastage due to pathogenic contamination, antimicrobials used for treatment or adulteration in appearance, and treatment expenditure. Oftentimes, indirect loses are not realized by the farmer as they are concealed. Many sources of indirect losses include pre-mature culling, decreased quality and quality of the harvested milk, expenditure on prevention and health problems associated with the disease and zoonotic potential (Gruet et al., 1999; du Preez et al., 2000; Bradley, 2002; Petrovski et al., 2006).

To date, more than 140 potentially pathogenic species such as bacteria (including Mycoplasma), fungi, algae, and viruses cause bovine mastitis (Watts, 1998; Petrovski et al., 2011). This is a big number of species for a single disease and could potentially alter the veterinarians' interpretation and determination of the epidemiology of the disease and resulting economic losses. As such, the infectious pathways of these causative pathogens should be addressed meticulously as some may overlap. Mastitis develops as one of two major types, namely contagious or environmental (Bradely, 2002), both of which severely damage the udder tissue of affected cows. Although 
routes and types of infection are universally accepted, etiologies of different pathogens, incidences, prevalence and management of mastitis are yet to be comprehensively documented for most African countries. As a result, costs remain underestimated and difficult to calculate, while existing treatment regimens are supported by limited evidence-based veterinary medicine. Consequently, these pitfalls hinder prevention, detection and treatment of the disease per cow, client and herd, and will ultimately impact negatively on dairy farming profitability.

Dairy production in Africa pales in comparison to the dairy industry in developed countries, such as the United States (US) and countries such as those in the European Union (EU), in terms of licensed herds (USAD, 2010; Lacto data, 2015). However, the average herd size is larger in African countries, including South Africa (USAD, 2010; Lacto data, 2015). Consequently, milk has become an important food commodity in African farming enterprises while its production is a source of income for commercial farmers. For many smaller farms, the dairy industry mainly feeds households because of milk production related labor requirement inputs, and generates income in poor communities. Several factors further influence the vitality of the dairy industry in many African communities. These include milking practices, processing, distribution, skilled human resources and indigenous beliefs, attitudes and values attached to consumption of dairy products including milk. Combined, these factors could influence mastitis management practices and associated policies presently held in Africa. Given this background, this review provides the current understanding of the occurrence and importance of bovine mastitis for the African continent. 


\section{The review process}

A review of the scientific literature was conducted following standard practices published by O'Connor et al. (2014) and Sargeant and O'Connor (2014). Databases and scientific search engines (e.g. African Journals Online, Web of Science, CAB Abstracts, PubMed, Google Scholars, ScieELO and Scopus) were searched for English language peer-reviewed articles, theses and reviews. General key terms, such as "mastitis", "mastitis pathogen", "mastitis organism", "mastitis cost", "mastitis economics", "dairy", "cattle", "cow" and "bovine", were used. Terms describing specific forms of mastitis were also used, including "mastitis algae", "mastitis bacteria", "mastitis fungus", "mastitis virus", "clinical mastitis" and "sub-clinical mastitis". All search terms were used as major descriptors and combined with search terms "Africa" or "African continent" or specific country names to specify prevalence locations. The search was enriched by doing a manual search in various journals, and was finalized in September 15, 2016. Papers retrieved were screened manually for relevance, focusing on full length articles reporting on mastitis from the African continent and excluding papers with no relevance to Africa. Additionally, reports published before the year 2000 were excluded, and this has limited the review to roughly the past decade and half.

Statistical analyses were conducted as follows. In terms of more than one paper being retrieved, provided that each was presenting data from different localities of a country, data was pooled. When multiple papers retrieved were presenting data from the same region in a country, an average of the data sets was calculated and used in the final analysis. Data for different countries was imported and saved into the StatPlanet data editor (StatSilk, 2012) using indicators "cows sampled", "disease prevalence", and "pathogen diversity". Integrative maps were constructed using StatPlanet version 3.0 
(StatSilk, 2012) and an online version of Plotly (https://plot.ly/plot/). Statistical data used to measure whole fresh milk production relative to animal trend in Africa was retrieved from the statistics division of the Food and Agriculture Organization of the United Nations (FAOSTAT, 2015).

\section{Milk production in Africa}

Milk is an important food and income source in developing countries. In sub-Saharan Africa and Asia, cattle account for about $75 \%$ and $50 \%$ of total milk produced, respectively. As shown in Fig. 1A, there has been an observable increase in milk producing animals and a concomitant increase in production of whole fresh milk across Africa (FAO, 2015). However, despite an increase in these two entities, analysis based on net milk production yield portrays a disturbing picture for certain African countries (Fig. 1B). For instance, although there has been an increase in the net yield between 2000 and 2013 in Egypt, Kenya and South Africa, other countries including Niger and Zimbabwe have encountered little, if any, gains during this period. Other countries, such as Algeria and Uganda, have experienced a sluggish increase in net milk production yield. A similar trend was observed in Asia, where buffaloes are major producers of milk, between 1999 and 2009 where only India, China and Pakistan experienced gains in milk production (Sharma et al., 2012). Countries including Bangladesh, Nepal and South Korea experienced sluggish gains, while Thailand, Vietnam and Sri Lanka experienced little to no gains (Sharma et al., 2012). These intercontinental milk variations can be attributed to numerous challenges including poor hygiene and/or servicing of malfunctioning milking equipment or milk storage bulk tanks. Lack of awareness among farmers regarding mastitis may also be a common cause. However, subclinical mastitis is an important contributor that is mutual between 
$\mathbf{A}$
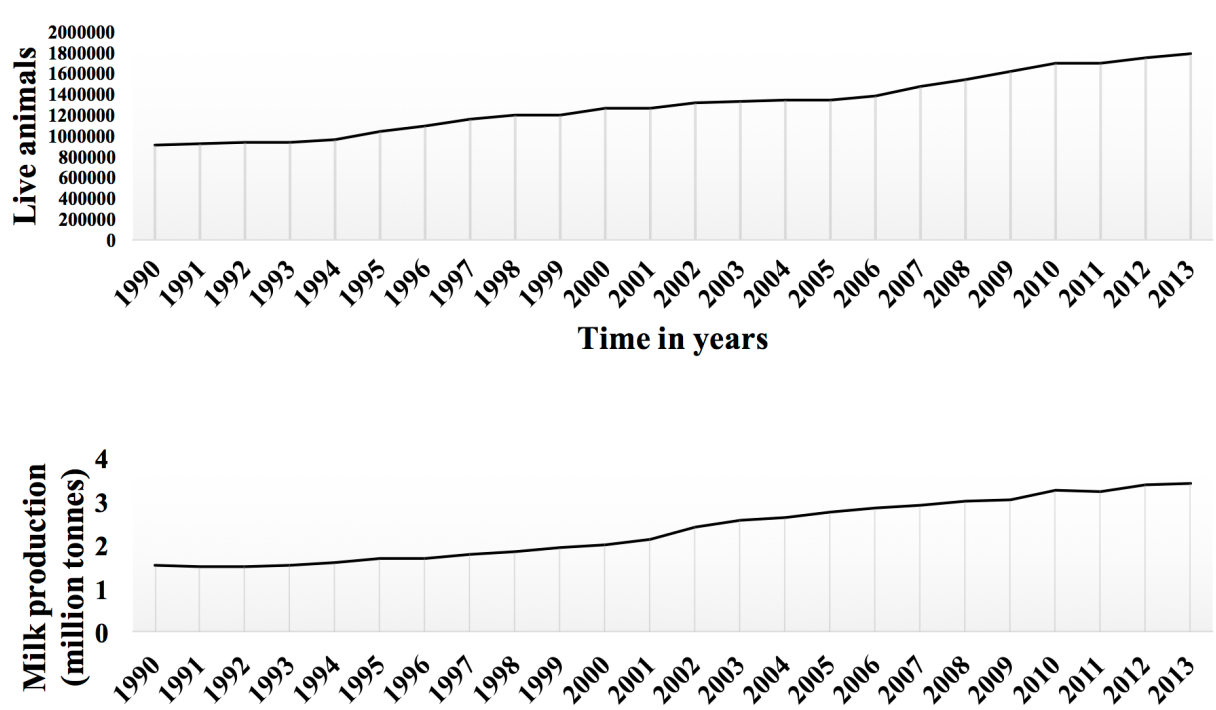

B

Time in years

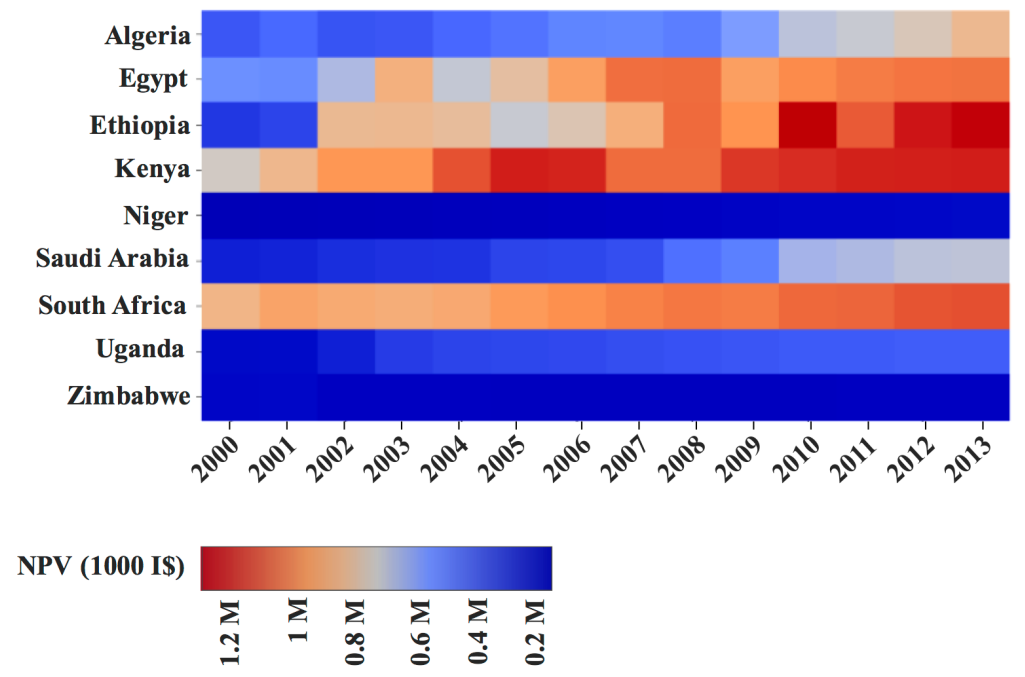

Fig. 1 Whole fresh cow milk production in Africa. A. Animal trend determined from number of cows in selected countries (Top) and milk production shared by region (Bottom). B. Milk production determined as Net Production Value (NVP) and expressed as international prices or US dollars (I\$) derived using a Geary-Khamis formula for the agricultural sector. Source: FAOSTAT (2015). 
Asia and Africa, accounting for substantial milk losses. This prompts studying of this disease on a continental scale in order to comprehend its prevalence and end results on milk production systems and the economy. Such analysis will identify severely affected countries in the developing world such as Africa and enable a combined effort to deal with the disease.

\section{Etiologies of bovine mastitis}

Clinical and subclinical mastitis is caused by more than 140 different pathogenic bacterial species (including Mycoplasma), in addition to fungi, algae, and viruses (Watts, 1998; Petrovski et al., 2011). Understanding the diversity of causative pathogens may help explain how they interact to produce intricate clinical patterns displayed by the disease. Since each country in each continent may have different cattle breeds, follow particular feeding mechanisms and influenced, to some extent, by particular cultural or indigenous beliefs, pathogen diversity may also vary in the different continents such as Africa, at herd, cow and quarter level. Below, a discussion on the etiologies of bovine mastitis and its relevance to the situation in Africa is provided.

\section{Bacterial mastitis}

The most common bacterial mastitis pathogens have been identified and classified into two distinct groups - contagious (or host-adapted) and environmental. Contagious mastitis involves introduction of pathogens during milking processes via milking equipment (e.g. malfunctioning pulsation and vacuum controllers) or milkers' hands. Some of the more commonly listed species which exploit this mode of transmission include Staphylococcus aureus, Streptococcus agalactiae, Corynebacterium bovis and Mycoplasma spp. 
Mycoplasma spp. show some differences in transmission, thus a brief discussion is warranted. Due to lack of a cell wall, Mycoplasma spp. can evade antimicrobial treatment that may target and disrupt the cell wall. Moreover, traditional tests rarely include Mycoplasma spp. in routine assessments, making cases of diagnosed Mycoplasma mastitis to be uncommon. Eventually, this hinders effective and rapid control measures that require early deployment. Such delays and a lack of effective detection system results in unforeseen and substantial economic consequences caused by Mycoplasma species. Affiliated species involved in Mycoplasma mastitis include, but are not limited to, M. bovis, M. bovigenitalium, M. californicum, $M$. canadense and M. alkalenscens. However, M. bovis is by far the most commonly isolated pathogen causing Mycoplasma mastitis on dairy farms globally. In addition to causing bovine mastitis, $M$. bovis is associated with a range of conditions including arthritis, reproductive (genital disorders) and respiratory diseases (pneumonia) (Pfützner and Sachse, 1996), which may exacerbate or be exacerbated by bovine mastitis. On the other hand, calves regarded as clinically healthy and young cattle tend to harbor $M$. bovis in the respiratory passages. Therefore, they can act as mutual reservoirs for this pathogen and will spread it across the herd, resulting in Mycoplasma bovine mastitis occurring at herd level. Transmission is thus facilitated through milk and respiratory mucus of infected cattle (Pfützner and Sachse, 1996).

Mycoplasma mastitis has been largely reported in parts of the US (Fox et al., 2003, 2008; Olde Riekerink et al., 2006; Roy et al., 2008; Punyapornwithaya, 2010), and less frequently reported in developing countries from Asia and Africa (Ghazaei, 2006; Saidi et al., 2013). Therefore, detection of Mycoplasma in bovine mastitis cases is deterred for the most part due to the requirement for specialized media and culturing techniques as well as an extended period of growth of more than seven days. The emergence 
and spread of Mycoplasma mastitis in developed countries suggests that outbreaks in the African countries are possible. But since an effective detection system is lacking in Africa, adverse economic effects will be hard to prevent. Therefore, research and laboratory diagnostics should focus on early detection.

Environmental mastitis is caused by pathogens found in the habitat of the cow, such as soil, plant material, manure, bedding, or a contaminated water source. Frequently, isolated causative pathogens that contribute to environmental bovine mastitis include members of streptococci and gram-negative bacteria, such as Escherichia coli and Klebsiella (Carrillo-Casas and Miranda-Morales, 2012). Both contagious and environmental mastitis result in subclinical and clinical forms with serious economic implications for the dairy industry in developing countries.

\section{Mycotic mastitis}

Fungi such as Aspergillus fumigatus, A. nidulans, Candida spp., Pichia spp. And Trichosporon spp. are known to cause mycotic mastitis. These fungi have been isolated in various parts of the world affected by mastitis, including Brazil, Poland, New Zealand and Tanzania (Mdegela et al., 2009; Williamson and di Menna, 2007; Wawron et al., 2010; Dworecka-Kaszak et al., 2012). However, mycotic mastitis is poorly characterized given the few studies conducted to characterize fungi in the context of this disease. In contrast, most studies have focused on prokaryotic etiologies, especially staphylococci. As a result, it remains unclear which fungal species is predominantly causing mycotic mastitis. Nonetheless, there is no compelling evidence to suggest that mycotic mastitis may not develop into a costly disease, as is the case

with bacterial mastitis, in any part of the world, but may certainly become a farmspecific problem. Since mycoses caused by fungi are common in mammals, such as 
humans and other warm blooded animals, the possibility of mycotic mastitis being costly should not be ignored.

\section{Algal mastitis}

Members of the algal order, Prototheca, cause incurable acute or chronic Protothecal mastitis in dairy cows. Protothecal species, such as $P$. zopfii (genotype 2) and $P$. wickerhamii, have been isolated in numerous clinical cases (Ranjan et al., 2006; Pieper et al., 2012; Sobukawa et al., 2012; Krukowski et al., 2013). Mastitis outbreaks due to several predisposing factors linked to Protothecal bovine mastitis range from animal age, prolonged use of antimicrobials to quarters with a history of clinical mastitis (Ranjan et al., 2006). Environments that are wet and humid tend to harbor Prototheca species. These environments include muddy pastures and pens, and the infection can occur when an injured teat is exposed to large pathogen numbers. Cattle immune status also plays a major role in infection establishment (Ranjan et al., 2006). Similar to Mycoplasma mastitis, the Protothecal form is rarely reported due to a lack of an effective detection system (Ranjan et al., 2006). Molecular typing tools, such as $18 S$ ribosomal DNA sequencing and restriction fragment length polymorphisms, have been applied in the detection of Prototheca cases of bovine mastitis in Brazil (Gonçalves et al., 2015), Canada (Peiper et al., 2012), Italy (Ricchi et al., 2012) and Japan (Osumi et al., 2008). Since data is already available for detection of Prototheca in bovine mastitis cases, a guide to identify such related cases in Africa can be formulated.

\section{Viral mastitis}

Viruses are isolated from cows affected with bovine mastitis although they are not regarded as common etiological factors. Therefore, these infectious agents should not be dismissed especially since algal, bacteriological and fungal agents do not account 
for $100 \%$ of mastitis cases. In addition, viruses, such as bovine herpesvirus (BHV), BHV4, foot-and-mouth disease virus and parainfluenza 3, have been associated with clinical bovine mastitis without isolation of bacterial pathogens (Wellenberg et al., 2002), suggesting that viral mastitis may indeed occur. However, the evidence is not sufficient to argue, with great certainty, that viruses are causative agents of bovine mastitis.

\section{Relevance to Africa}

To address relevance of mastitis causing pathogens to certain African regions, papers reporting the different pathogenic species isolated from Botswana, Ethiopia, Nigeria, Sudan and Zambia were assessed. These regions show the highest variability in pathogens causing mastitis (>10; Fig. 2A). Kenya and Niger showed between six and seven pathogens, while South Africa, Tanzania, Uganda and Zimbabwe showed fewer than six different pathogens (Fig. 2A). The most commonly reported pathogens were S. aureus, S. agalactiae, S. dysgalactiae, S. uberis, and E. coli., while S. aureus was the predominant pathogen identified in milk samples from across Africa (Fig. 2B). This mastitic pathogen had the highest prevalence in Kenya (>70\%) and lowest prevalence compared to other pathogens in South Africa at less than $10 \%$ (Fig. 2B). An early survey examining distribution patterns of mastitis causing pathogens between 1996 and 2007 also reported that $S$. aureus isolates occurred in relatively low numbers (between $10 \%$ and $20 \%$ ) compared to other pathogens in South Africa (Petzer et al., 2009). Several factors, such as climatic conditions, cattle nutrition in feed stocks or movement of cattle between herds, may influence the geographical distribution and dynamics of $S$. aureus and other pathogens. A larger sample size will be more informative in establishing continental prevalence of bovine mastitis and pathogen diversity. 
A

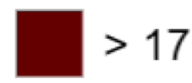

$15.3-17$

$13.6-15.3$

$11.9-13.6$

$10.1-11.9$

$8.4-10.1$

$6.7-8.4$

$5-6.7$

$<5$

No data
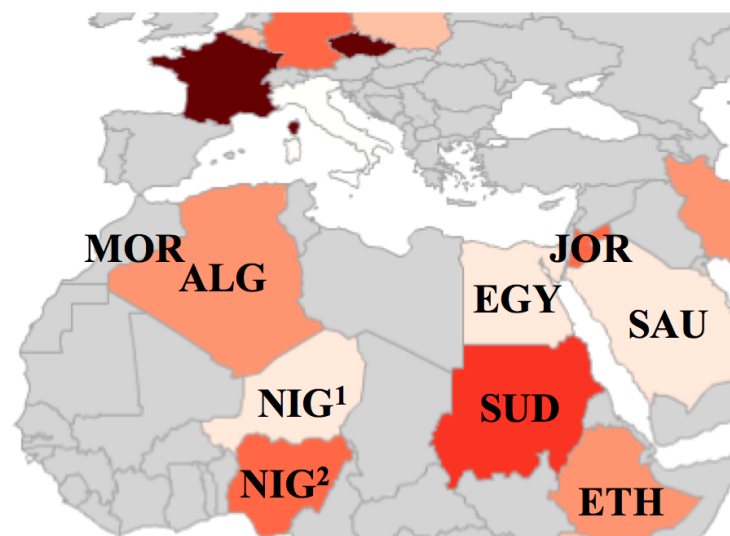

B
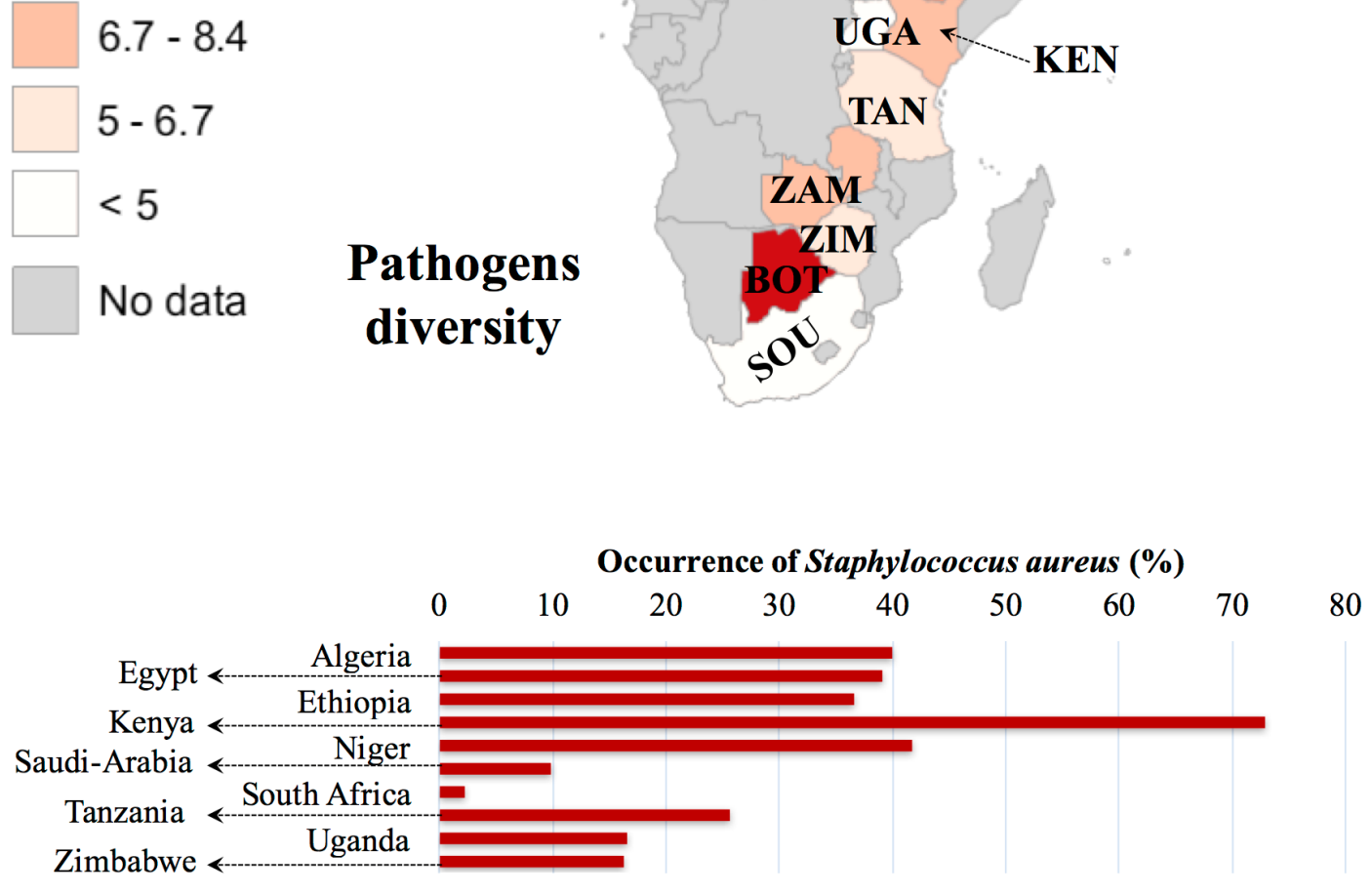

Fig. 2 Continental outlook of causative pathogens in Africa. A. Pathogen diversity. Abbreviations of countries are the same as in Fig. 1. B. Prevalence of Staphylococcus aureus in selected African regions. 


\section{The influence of bovine mastitis in Africa}

Incidence and prevalence of clinical and sub-clinical mastitis has been reported for many regions of the world. Most reports come from developed countries, with some reported by Bradley (2002) and Petrovski et al. (2009). Sharma and associates (2012) reviewed the impact of bovine mastitis on Asian cattle and buffaloes. In Africa, occurrence of this disease is well documented in $30 \%$ of countries. However, a unified presentation of findings from various studies that is continental for this disease in Africa is needed and will be attempted in this section.

Based on recent reports, released from 2011 to 2014 (Basdew and Laing, 2011; Saidi et al., 2013; Gitau et al., 2014; Kassa et al., 2014), negative effects of bovine mastitis on the African economy could be overwhelming. Therefore, evidence-based intervention is warranted. Data compiled from several reports shows that mastitis is generally of bacterial in nature, with the predominant species being $S$. aureus. A large number of reports were reviewed for this paper to demonstrate overall prevalence of bovine mastitis at the clinical and subclinical level in African bovine herds. Reports published from 2000 to 2014 based on surveys from small and large dairy farms in sub-Saharan Africa, with a few coming from the Middle-East and north Africa (Figure 2-5), suggest that efforts to develop effective and economical methods for disease treatment may be fast-tracked in some regions and less intense in some. To address the extent to which bovine mastitis affected Africa, several aspects such as sample size, reported cases and resultant losses as well as the economic aspects in regions selected based on published reports were analyzed. 


\section{Sample size}

In general, the Middle-Eastern and north African regions have a large number of sampled animals [Morocco (circa 1,700), Jordan (circa 16,900) and Saudi Arabia (circa 11,200)] compared with other countries (Fadlelmula et al., 2009; Alekish et al., 2013; Boujenane et al., 2015) (Fig. 3). Less than 1,000 cows were surveyed for bovine mastitis in most reports, with Nigeria, Tanzania and Uganda having the lowest number of surveyed animals $(\leq 200)$. The reasons for various sample sizes are most likely multifactorial and can range from poor accessibility to milk samples to extent of the disorder not being recognized. Lack of collaboration between practicing veterinarians holding mastitis data and scientists undertaking surveys may also be a cause of variability in sample size. Whatever the reason for observed variability in available sample size, only a margin of the African continent has been represented with some literature of prevalence and incidence of this disease, suggesting that Africa is progressing at a slower pace, compared to other continents, in surveying the disease.

\section{Reported cases of clinical and subclinical mastitis}

Udder health directly and indirectly imposes economic burden on dairy farms worldwide. Although initial impact is usually experienced at farm level, udder health issues may escalate to national and continental scale if not detected and addressed in a timely manner. This requires national monitoring system of mastitis occurrence to ensure treatment measures are sanctioned to reduce financial losses. As is the case for continents such as Asia, in Africa mastitis has been profiled in terms of clinical and subclinical forms, both of which contribute to disease prevalence (Fig. 3A). Notably, all reports evaluated in this review unanimously show that subclinical mastitis is steadily increasing, and this is likely the case in regions for which data is not yet published. Accordingly, countries in which disease prevalence is high, such as Ethiopia, Kenya, South Africa and Uganda, display high prevalence of subclinical 


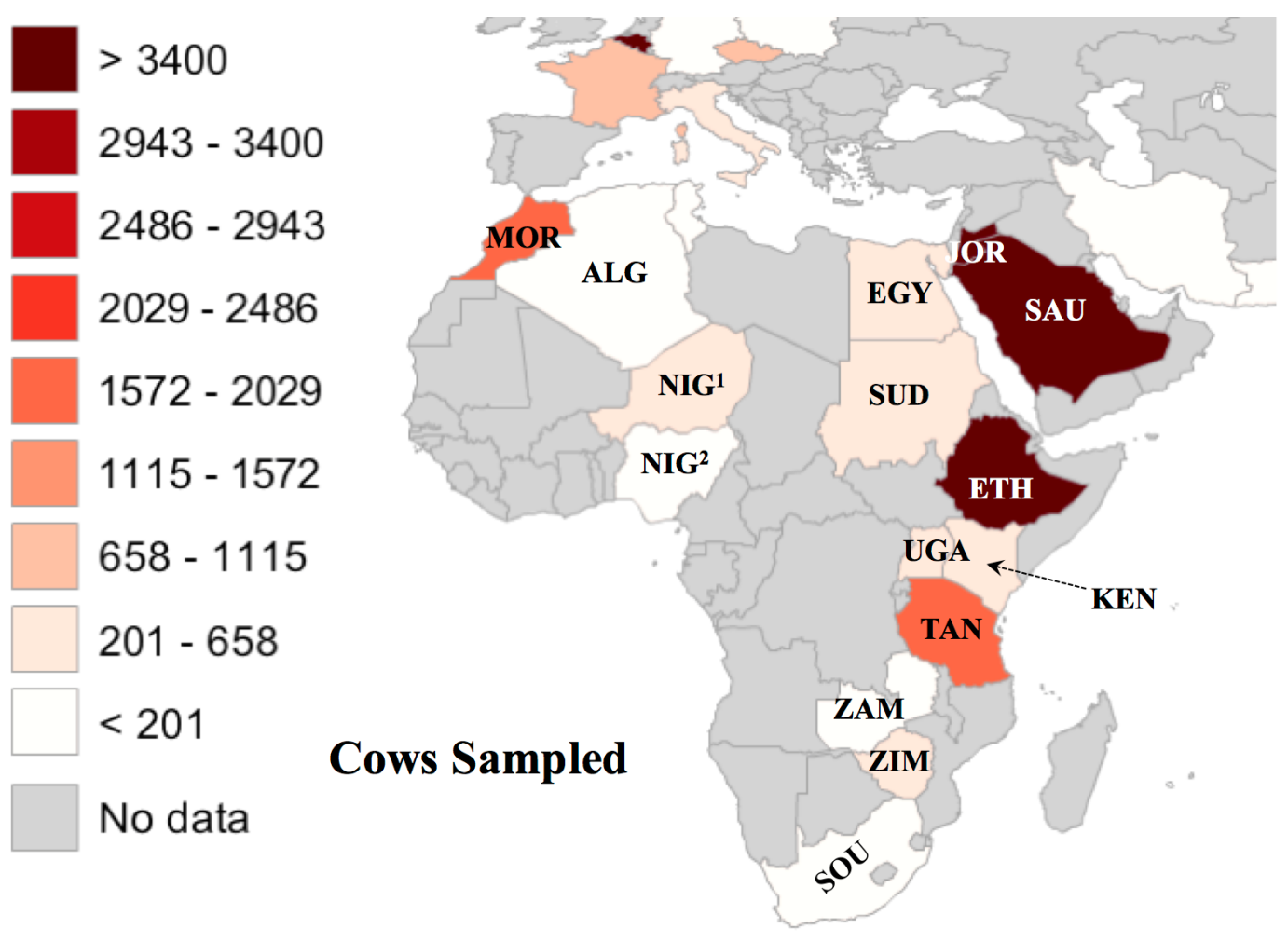

Abbreviations to Countries

ALG - Algeria, BOT - Botswana, EGY - Egypt, ETH - Ethiopia, JOR - Jordan, KEN - Kenya, MOR - Morocco, NIG $^{1}$ - Niger, NIG ${ }^{2}$ - Nigeria, SAU - Saudi Arabia, SOU - South Africa, SUD - Sudan, TAN - Tanzania, UGA Uganda, ZAM - Zambia, ZIM - Zimbabwe

Fig. 3 Integrative map showing sample size used in bovine mastitis. Data compiled from reports published between 2000 and 2015 . Abbreviations to country names are the same as in Fig. 2. 
mastitis of between $60 \%$ and $80 \%$ (Fig. 3B). Interestingly, more papers reporting on clinical and subclinical mastitis were published in Ethiopia than in any other subSaharan African country (Fig. 4). These reports show that $>3,400$ cows have been tested for clinical and subclinical mastitis in dairy herds scattered in and around Ethiopia over the past decade or so (Dego and Tareke, 2003; Sori et al., 2005; Lakew et al., 2009; Abebe et al., 2010; Bitew et al., 2010; Mekibib et al., 2010; Moges et al., 2011; Almaw et al., 2012; Daka et al., 2012; Girma et al., 2012; Haftu et al., 2012; Tadesse and Chanie, 2012; Abera et al., 2013; Belayneh et al., 2013; Yohannis and Molla, 2013; Zeryehun et al., 2013; Benti and Zewdie, 2014; Hailemeskel et al., 2014; Zenebe et al., 2014). This suggests that some African countries have higher prevalence of bovine mastitis than others, and may be more involved in dealing with disease detection, treatment and impacts than other countries.

Although data from reviewed reports reflects information based on one visit per farm for most surveys, a general view of mastitis occurrence can be inferred. For instance, prevalence of subclinical mastitis between 2005 and 2012 was around $40 \%$, while the clinical form was below this number until 2014 (Fig. 4); clinical signs of mastitis are easily detected, thus can be dealt with as soon as they appear. Whether this points to a common factor, such as the time of year (season) when samples were collected or common feeding schemes, remains a matter of speculation and demands further inquiry. Another generalization that can be made is that the occurrence of subclinical mastitis is predominantly higher than clinical mastitis in surveyed areas of Ethiopia, consistent with most parts of Africa (Fig. 3B). Therefore, prevalence of subclinical mastitis in Ethiopia and other African regions may impose substantial costs due to indirect losses (Petrovski et al., 2006; Halasa et al., 2007). To this effect, cumulative 
$\mathbf{A}$

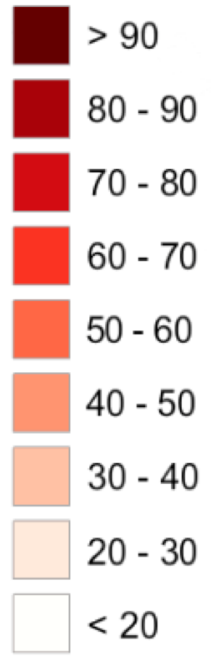

No data

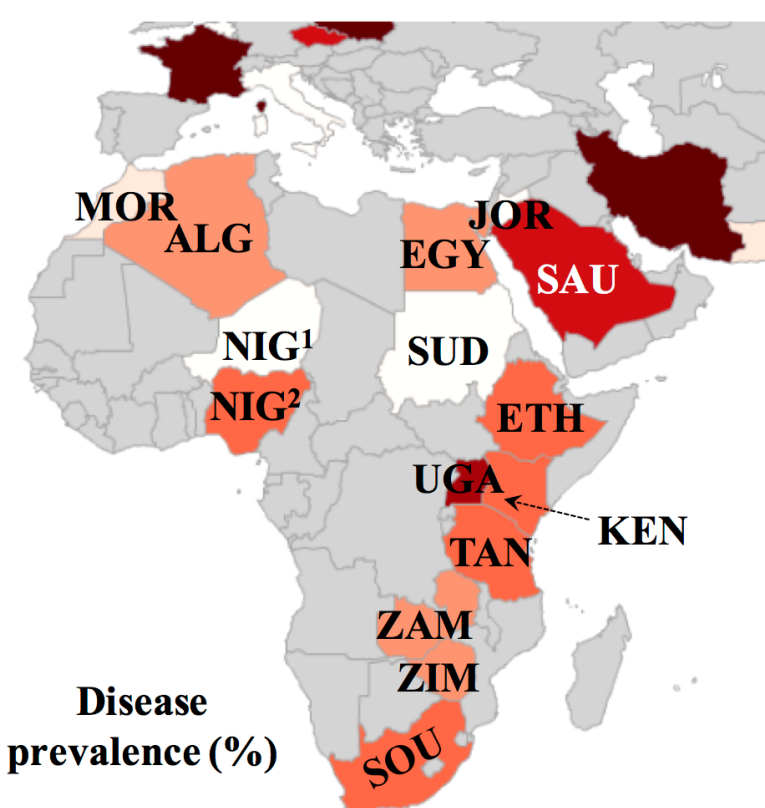

B
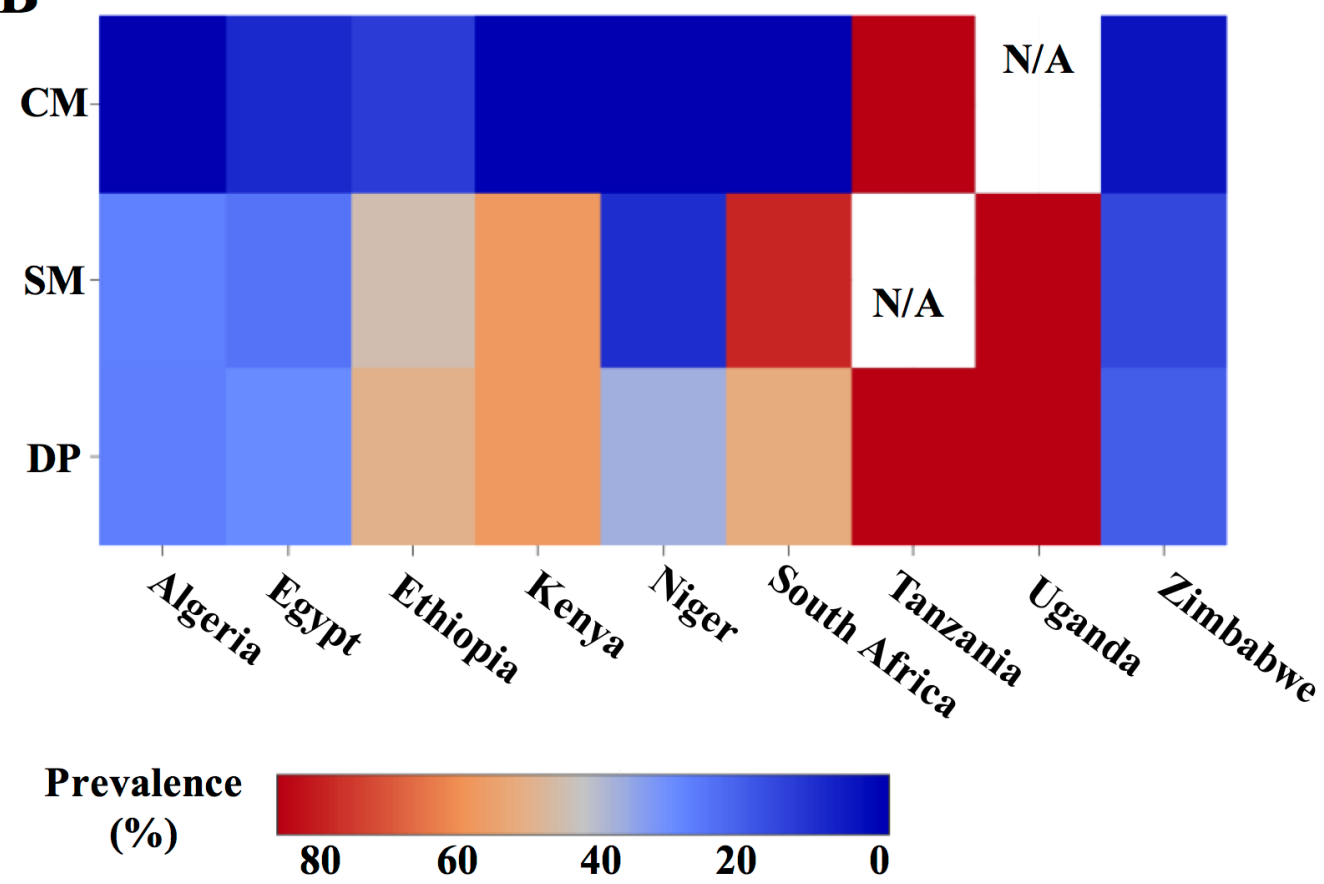

Fig. 4 Continental outlook of bovine mastitis. A. Prevalence at cow or quarter level. B. Relationship between quarter prevalence (QP), disease prevalence (DP), subclinical mastitis (SM) and clinical mastitis (CM). N/A, data not available. Abbreviations of countries are the same as in Fig. 2. 


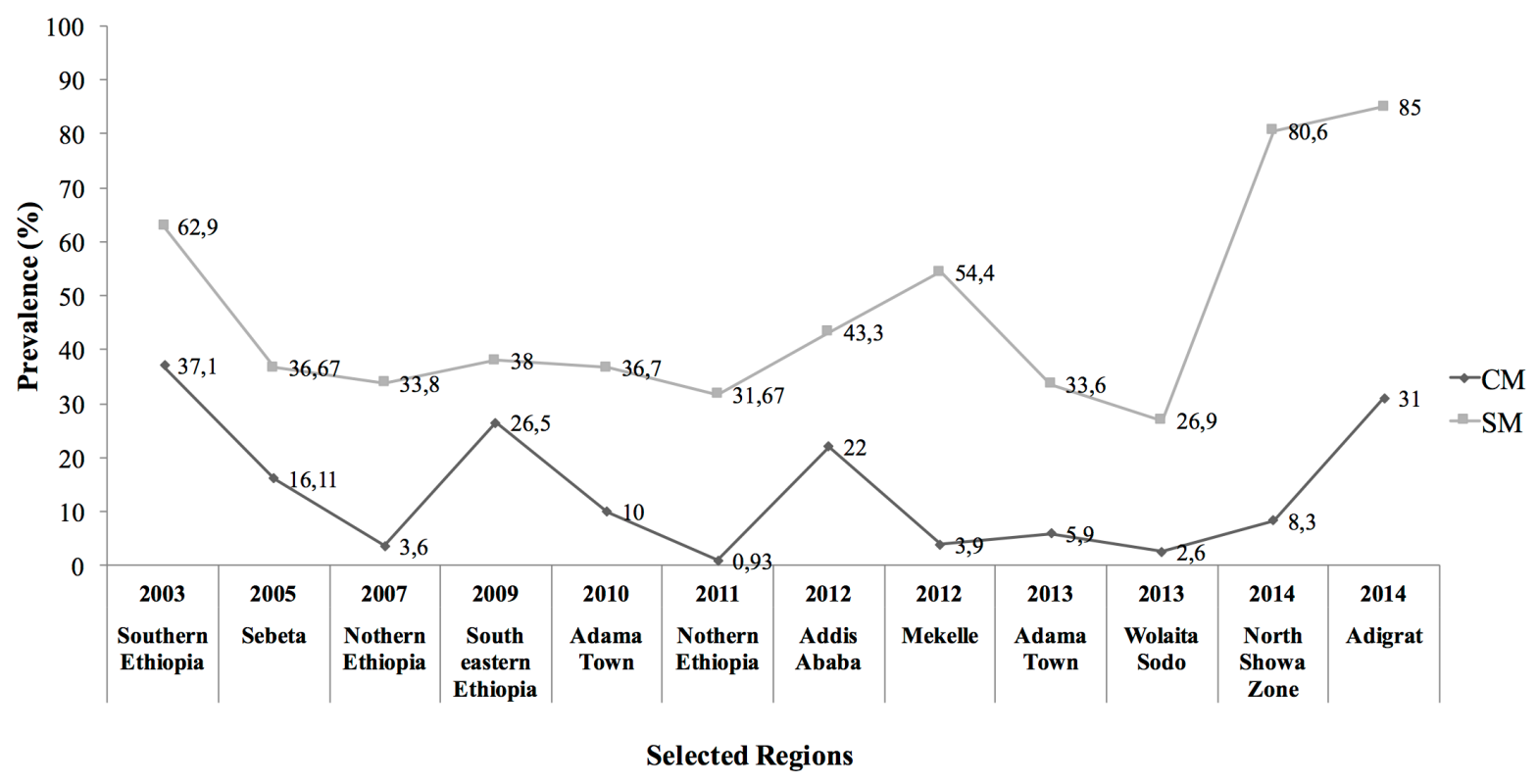

Fig. 5 Mastitis prevalence in selected Ethiopian regions. CM, clinical mastitis; SM, sub-clinical mastitis. 
data from Ethiopia can serve to develop a large-scale disease control program for other African countries.

\section{Prevalence at cow or quarter level}

Infections that occur at cow's quarters are good indicators of mastitis' prevalence at animal level. This was the baseline to determine mastitis at this level in the African continent. Reports of cows with one or more udder quarters infected with clinical and/or subclinical mastitis for the African continent were gathered and examined. According to these reports, most countries display between $30 \%$ and $60 \%$ prevalence, with circa 30 to $40 \%$ infection in Morocco and Ethiopia and less than $13 \%$ infection in Niger and Sudan (Fig. 3A). Saudi Arabia, located north of Africa, showed the highest percentage of mastitis infected cows (>70\%) from a relatively large sample size (Fadlelmula et al., 2009). Evidence-based information of the prevalence of bovine mastitis in Africa could be maintained by sampling different localities at least twice or three times a year.

\section{Reported losses}

Economic losses associated with bovine mastitis in developed countries are well documented. These include annual losses estimated per cow per year in the US and EU countries (Blosser, 1979; Morin et al., 1993; Yalcin, 1999; Costello, 2004; Halasa et al., 2009; Viguier, 2009). In contrast, the economic impact of bovine mastitis in Africa is not well documented due to a lack of published material. Therefore, production losses and expenditure associated with mastitis in Africa and other developing countries are generally underestimated and potentially miscalculated (FAO, 2014). In addition, different countries around the world apply distinct methodologies to calculate economic losses incurred due to mastitis (some examples 
Table 1 Estimated costs incurred due to bovine mastitis in selected developing countries (FAO, 2014).

\begin{tabular}{|c|c|c|c|c|c|c|}
\hline Area & $\begin{array}{l}\text { Milk } \\
\text { loss } \\
(\%)\end{array}$ & Costs (\$) & Method(s) & Mastitis $^{b}$ & $\begin{array}{l}\text { Production } \\
\text { system }^{c}\end{array}$ & Period \\
\hline Ethiopia & 5.6 & $38 /$ cow & $\begin{array}{l}\text { Production losses } \\
\text { due to sub-clinical } \\
\text { mastitis per } \\
\text { subsystem level }\end{array}$ & $\begin{array}{l}\mathrm{CM} \text { and } \\
\mathrm{SM}\end{array}$ & $\begin{array}{l}\text { Urban, peri- } \\
\text { urban and } \\
\text { dairy herds in } \\
\text { secondary } \\
\text { towns }\end{array}$ & 2005 \\
\hline Madagascar & $\mathrm{N} / \mathrm{A}$ & $188 /$ cow & $\begin{array}{l}\text { Financial loss due } \\
\text { to CM per cow }\end{array}$ & $\mathrm{CM}$ & Peri-urban & 2004 \\
\hline India & 17.5 & $\begin{array}{l}\mathrm{CM}=91 \text { (cows) } \\
\text { and } 75 \\
\text { (buffaloes); SM } \\
=192 \text { (cows) } \\
\text { and } 154 \\
\text { (buffaloes) }\end{array}$ & $\begin{array}{l}\text { Milk losses/ } \\
\text { animal/ lactation; } \\
\text { economic loss due } \\
\text { to reduced milk } \\
\text { production; Cost of } \\
\text { milk discarded due } \\
\text { to CM/animal }\end{array}$ & $\begin{array}{l}\mathrm{CM} \text { and } \\
\mathrm{SM}\end{array}$ & $\mathrm{N} / \mathrm{A}$ & $\begin{array}{l}1962 \\
1994\end{array}$ \\
\hline
\end{tabular}

a"\$", cost estimates calculated in US dollars

${ }^{\mathrm{b}} \mathrm{CM}$, clinical mastitis; SM, subclinical mastitis

${ }^{\mathrm{N}} \mathrm{N} / \mathrm{A}$ - Not applicable 
are indicated in Table 1), and this makes comparison difficult (FAO, 2014). Therefore, to estimate economic impacts of bovine mastitis, a universal method is needed. As far as Africa is concerned, the research landscape for analysis of economic effects associated with bovine mastitis is wide open.

\section{Reported interventions}

A recent study conducted in South Africa to evaluate economic value of somatic cell count (SCC) in Holstein and Jersey cattle found that it is imperative for SCC to be incorporated into breeding objectives. A reduction in milk yields caused a concurrent profit reduction ranging from ZAR 491.48 to ZAR 1,795.57 per cow per year, depending on the breed, production and payment system (Banga et al., 2014). To our knowledge, these estimated profit reductions were derived from milk of healthy cows, arguing that reductions are potentially severe in cows with subclinical mastitis. Therefore, information on milk SCC is vital in detecting subclinical mastitis as it may provide reliable estimates of milk production losses.

\section{Mastitis diagnosis}

Diagnosis of clinical mastitis is less complex since clinically discernable signs, including swollen quarters/udder and poor milk quality, can be detected by farmers (Mahmmod, 2013). By contrast, subclinical mastitis cannot be visually diagnosed and requires application of diagnostic techniques. The wide range of mastitis causing pathogens can perpetuate the costs of developing treatment, and in some cases, may involve application of diagnostic methods tailored to specific pathogens.

Under field conditions, early detection is often assisted using traditional diagnostic tests, such as the California Mastitis Test (CMT) and/or SCC at herd level (Deb et al., 2013; Duarte et al., 2015). CMT is a simple cow-side indicator test commonly used to 
determine SCC for diagnosis of subclinical mastitis. Somatic cells mainly comprise of macrophages, lymphocytes, erythrocytes and epithelial cells (Dohoo and Meek, 1982; Pillai et al., 2001; Sharma et al., 2011) and the proportion of each cell type depends on infection status of the gland. In healthy udders, white blood cells constitute a third of cells, but during infection white blood cells may increase in proportions, reaching $99 \%$. Therefore, SCC can indicate the presence and extent of udder tissue damage caused by pathogenic species or malfunctioning milking equipment and, hence, safeguard milk quality. Consequently, regular examination of somatic cells in milk is recommended for dairy farms, despite the lack of a universal standard that exists for SCC in terms of poor or good milk quality. Additionally, an inverse linear relationship has been defined between low SCC (e.g. $<100,000$ cells $/ \mathrm{mL})$ and high milk quality as well as high SCC (e.g. $>200,000$ cells $/ \mathrm{mL}$ ) and declining milk quality (Bradley, 2002; Sharma et al., 2011). Such measures should be considered for Africa to timely curb disease consequences.

Other common tests for detection of bovine mastitis include electrical conductivity, $\mathrm{pH}$, $\mathrm{NaOH}$ (white side test), measurement of $\mathrm{N}$-acetyl-b-D-glucosaminidase, lactate dehydrogenanse, bacterial culture of milk, and milk enzyme-linked immunosorbent assay as well as polymerase chain reaction (PCR) assay (Mahmmod, 2013). Several PCR assays, including multiplex PCR and real-time (RT)-PCR, have been developed for detection of mastitic pathogens including Staphylococcus spp., E. coli, M. bovis, S. agalactiae and Enterococcus spp. (Taponen et al., 2009; Koskinen et al., 2009; Shome et al., 2011; Hiitiö et al., 2015; Barbier et al., 2016). A comprehensive background of the molecular epidemiology of mastitis pathogens, particularly at sub-species level, with relevance to public health is reported by Zadoks et al. (2011). The advent of the loop-mediated isothermal amplification method, which is another nucleic acid 
amplification technique (Tomita et al., 2008), has seen development of assays for detection of Staphylococcus spp., E. coli, M. bovis, S. agalactiae and Enterococcus spp. (Kato et al., 2007; Zhang et al., 2011; Wang et al., 2015; Bosward et al., 2016).

Other molecular biological techniques developed for diagnosis of bovine mastitis include proteomics-based detection, biochips and biosensors (Deb et al., 2013). Therefore, an inventory of diagnostic techniques exists, and can be applied as a first line of detection from milk samples in African countries. The challenge is to select a technique(s) with most of desirable qualities (e.g. most reliable, relevant and rapid) to facilitate detection and downstream analyses.

\section{Mastitis treatment}

Developing an effective mastitis therapy remains a challenge for researchers due to high number of pathogens contributing to the disease. S. aureus is the most prevalent species in bovine mastitis due to resistance mechanisms, such as formation of abscesses within the udder (du Preez, 2000) or evasion of antibiotics by residing inside macrophages, thus avoiding antibiotics circulating in the bloodstream. Moreover, some strains of $S$. aureus can exist as latent bacteria within a capsule and can later reactivate growth when conditions normalize (du Preez, 2000). Furthermore, treatment is complicated by the presence of planktonic and biofilm growth. Evasion of, and resistance to, antibiotics as well as latency have obvious implications for treatment and costs. These factors are important to the success of $S$. aureus as a mastitic pathogen prevailing in Africa.

Currently, there is no universal procedure to treat mastitis. For most treatment campaigns recommended treatment depends on the extent of udder health deterioration (du Preez, 2000). In South Africa, an interesting development is the 
exploration of phages as an alternative therapy (Basdew and Laing, 2011; Basdew, 2012). Phages offer a number of benefits as natural therapeutic agents to control bacterial pathogens. These include host specificity, reduced toxicity, ease of isolation and propagation, prolonged shelf life and availability in the same environment as their bacterial hosts. Therefore, problems associated with antimicrobials, such as resistance, cost, and the need to continuously develop antimicrobials in response to their targets, can be eradicated as phages presumably evolve with the target host. However, it is possible that bacteria could develop mechanisms to avoid attack and killing by bacteriophages. Bacteria may secrete enzymes that target phage receptors on cell wall surfaces preventing recognition by, or altering specificity of, phages. As $S$. aureus is the dominant etiological agent in bovine mastitis in Africa, the great potential of bacteriophage therapy is currently being tailored for controlling strains of this species (Basdew and Laing, 2011; Basdew, 2012). Application of phage therapy should be expanded to accommodate other pathogens as antibiotic resistance is not limited to $S$. aureus alone.

\section{Conclusions and future directions}

More work is required for reliably diagnosing and treating bovine mastitis, as well as estimating the resulting economic impacts in Africa. Whilst culture-based techniques allow strain isolation from field samples, molecular genetic techniques undoubtedly offer rapid, specific and sensitive detection pipelines for mastitis. Nonetheless, African countries can largely benefit from developing a clear policy regarding diagnosis. Such a policy should emphasize application of rapid techniques as a first line of diagnosis for suspected infections, outbreaks, or be used during routine testing and confirmation at reference centers. As indicated in this paper, prevalence of subclinical mastitis is definitely on the rise in Africa, ranging from $50-80 \%$ in Ethiopia, Kenya, South Africa 
and Uganda. This is concerning since this form of mastitis leads to increased antimicrobial resistance observed in most mastitis causing pathogens and is by far the damaging and costly form of the disease as early detection is difficult. Thus, this review has highlighted some of the countries severely affected by subclinical mastitis, and should serve as a guide to strengthen subsequent analyses. As subclinical mastitis is common in affected cows and results in elevated SCC, it is recommended that there be clear communication regarding SCCs acceptable for a healthy udder in Africa. This will inform the initiation of treatment for potentially affected cattle. It is also important to address the issue of accuracy when using SCC to detect subclinical mastitis as farmers rely on this information to administer antimicrobials during therapy.

Only about $30 \%$ of African countries report cases of bovine mastitis, while $\sim 70 \%$ lag behind. This is a small number compared to the developed world. Additionally, estimates of milk losses and costs of dealing with the disease are not well documented, suggesting that there is a delay in devising effective combat strategies. Measures such as increasing collaborations between the dairy industry, scientific community and economists, would result in the better use of limited resources and expertise. It is also advisable that farmers do regular cattle screening for subclinical and clinical signs of mastitis in order to eminently deal with direct and indirect losses.

\section{Acknowledgements}

Authors are grateful to $L$. Mwadzingeni for comments received during preparation of this manuscript. TEM is supported by the National Research Foundation (NRF) of South Africa (Grant no. SFP14070774252). The financial assistance of the NRF is hereby acknowledged. Opinions expressed and conclusions arrived at, are those of the author and not necessarily attributed to the NRF. 


\section{References}

Abebe G, Ike AC, Siegmund-Schultze M, Mane-Bielfeldt A and Zarate AV (2010). Prevalence of mastitis and Brucellosis in cattle in Awassa and the peri-urban areas of two smaller towns. Zoonoses and Public Health 57: 367-374.

Abera B, Lemma D and Iticha I (2013). Study of bovine mastitis in asella government dairy farm of Oromia Regional state, South Eastern Ethiopia. International Journal of Current Research and Academic Review 1: 134-145.

Alekish MO, Al-Qudah KM and Al-Saleh A (2013). Prevalence of antimicrobial resistance among bacterial pathogens isolated from bovine mastitis in northern Jordan. Revue De Medecine Veterinaire 164: 319-326.

Almaw G, Molla W and Melaku A (2012). Incidence rate of clinical bovine mastitis in selected Incidence rate of clinical bovine mastitis in selected. Ethiopian Veterinary Journal 16: 93-99.

Banga C, Neser F, and Garrick D (2014). The economic value of somatic cell count in South African Holstein and Jersey cattle. South African Journal of Animal Science 44: 174-177.

Barbier E, Boschiroli ML, Gueneau E, Rochelet M, Payne A, de Cruz K, Blieux AL, Fossot C and Hartmann A (2016). First molecular detection of Mycobacterium bovis in environmental samples from a French region with endemic bovine tuberculosis. Journal of Applied Microbiology. Doi:10.1111/jm.13090.

Basdew IH (2012). Biological and molecular characterization of South African bacteriophages infective against Staphylococcus aureus subsp. aureus Rosenbach 1884, causal agent of bovine mastitis. School of Agriculture, Earth 
and Environmental Sciences, Faculty of Science and Agriculture, University of KwaZulu-Natal, Republic of South Africa.

Basdew IH, and Laing MD (2011). Biological control of bovine mastitis using bacteriophage therapy. In: A Méndez-Vilas (Eds), Science against microbial pathigens: comunicating current research and technological adavances. Formatex 1: 386-393.

Belayneh R, Belihu K and Wubete A (2013). Dairy cows mastitis survey in Adama Town, Ethiopia. Journal of Veterinary Medicine and Animal Health 5: 281-287.

Benti AD and Zewdie W (2014). Major reproductive health problems of indigenous Borena cows in Ethiopia. Journal of Advanced Veterinary Animal Research 1: $182-188$.

Bitew M, Tafere A and Tolosa T (2010). Study on bovine mstitis in dairy farms of Bahir Dar and environs. Journal of Animal and Veterinary Advances 9: 2112-2917.

Blosser TH (1979). Economic losses from, the national research programme on, mastitis in the United States. Journal of Dairy Science 62: 119-127.

Bosward KL, House JK, Deveridge A, Mathews K and Sheehy PA (2016). Development of loop-mediated osothermal amplification assay for the detection of Streptococcus agalactiae. Journal of Dairy Science 99: 2142-2150.

Bradley AJ (2002). Bovine mastitis: An evolving disease. The Veterinary Journal 164: $116-128$.

Carrillo-Casas EM and Miranda-Morales RE (2012). Bovine mastitis pathogens: Prevalence and effects on somatic cell count. In: N Chaiyabutr, Milk Production 
Milk production-an up to-date overview of animal nutrition, management and health. INTECH, New York. 2012: 359-74.

Costello S (2004). Consultant guide to economics of mastitis. [Available online at www.smartstock-usa.com]. Accessed on 20 June 2016.

Daka D, G/silassie S and Yihdego D (2012). Antibiotic-resistance Staphylococcus aureus isolated from cow's milk in the Hawassa area, South Ethiopia. Annals of Clinical Microbiology and Antimicrobials 11: 1.

Deb R, Kumar A, Chakraborty S, Verma AK, Tiwari R, Dhama K, Singh U and Kumar S (2013). Trends in diagnosis and control of bovine mastitis: A review. Pakistan Journal of Biological Sciences 16: 1653-1661.

Dego OK and Tareke F (2003). Bovine mastitis in selected areas of Southern Ethiopia. Tropical Animal Health and Production 35: 197-205.

Dhanda MR and Sethi MS (1962). Investigation of mastitis in India. Indian Council of Agricultural Research 1962.

Dohoo I and Meek A (1982). Somatic cell counts in bovine milk. Canadian Veterinary Journal 23: 119-125.

du Preez JH (2000). Bovine mastitis therapy and why it fails. Journal of the South African Veterinary Association 71: 201-208.

Duarte CM, Freitas PP and Bexiga R (2015). Technological advances in bovine mastitis diagnosis: an overview. Journal of Veterinary Diagnostic Investigation 27: 665-672. 
Dworecka-Kaszak B, Krutkiewicz A, Szopa D, Kleczkowski M and Bieganska M. (2012). High prevalence of Candida yeast in milk samples from cows suffering from mastitis in Poland. The Scientific World Journal 2012.

Fadlelmula A, Dughaym AM, Mohamed GE, Deib MK and Zubaidy AJ (2009). Bovine Mastitis: Epidemiological, clinical and etiological study in a Saudi Arabian large dairy farm . Bulgarian Journal of Veterinary Medicine 12: 199-206.

FAO (2014). Impact of mastitis in small scale dairy production systems. Animal Production and Health Working Paper 13, Rome. [Available online at www.fao.org/3/a-i3377e]. Accessed on 20 June 2016.

FAO (2015). [Available online at http://www.fao.org/]. Accessed on 20 June 2016.

FAOSTAT (2015). FAOSTAT online database [Available online at http://faostat3.fao.org/download/Q/*/E]. Accessed on 20 June 2016.

Fox LK, Hancock DD, Mickelson A and Britten A (2003). Bulk tank milk analysis: Factors associated with appearance of Mycoplasma sp. in milk. Journal of Veterinary Medicine B, Infectious diseases and Veterinary Public Health 50: 235-240.

Fox LK, Muller FJ, Wedam ML, Schneider CS and Biddle MK (2008). Clinical Mycoplasma bovis mastitis in prepubertal heifers on 2 dairy herds. Canadian Veterinary Journal 49: 1110-1112.

Ghazaei C (2006). Mycoplasmal mastitis in dairy cows in the Moghan region of Ardabil State, Iran. Journal of the South African Veterinary Association 77: 222-223. 
Girma S, Mammo A, Bogele K, Sori T, Tadesse F and Jibat T (2012). Study on prevalence of bovine mastitis and its major causative agents in West Harerghe zone, Doba district, Ethiopia. Journal of Veterinary Medicine and Animal Health 4: 116-123.

Gitau GK, Bundi RM, Vanleeuwen J and Mulei CM (2014). Mastitogenic bacteria isolated from dairy cows in Kenya and their antimicrobial sensitivity. Journal of the South African Veterinary Association 85: 01-08.

Gonçalves JL, Lee SHI, de Paula Arruda E, Galles DP, Caetano VC, de Oliveira CAF, Fernandes AM and dos Santos MV (2015). Biofilm-producing ability and efficiency of sanitizing agents against Prototheca zopfii isolates from bovine subclinical mastitis. Journal of Dairy Science 98: 3613-3621.

Gruet P, Maincent P, Berthelot X and Kaltsatos V (2001). Bovine mastitis and intramammary drug delivery: review and perspectives. Advanced Drug Delivery Reviews 50: 245-259.

Haftu R, Taddele H, Gugsa G and Kalayou S (2012). Prevalence, bacterial causes, and antimicrobial susceptibility profile of mastitis isolates from cows in largescale dairy farms of Northern Ethiopia. Tropical Animal Health Production 44: $1765-1771$.

Hailemeskel D, Admasu P and Alemu F (2014). Prevalence and identification of bacterial pathogens causing bovine mastitis from crossbred of dairy cows in North Showa zone of Ethiopia. Global Veterinaria 13: 189-195.

Halasa T, Huijps K, Østerås O and Hogeveen H (2007). Economic effects of bovine mastitis and mastitis management: a review. Veterinary Quarterly 29: 18-31. 
Halasa T, Nielen M, Roos APW, Van Hoorne R, de Jong G, Lam TJGM, van Werven T and Hogeveen $H$ (2009). Production loss due to new subclinical mastitis in Dutch dairy cows estimated with a test-day model. Journal of Dairy Science 92 : 599-606.

Hiitiö H, Riva R, Autio T, Pohjanvirta T, Holopainen J, Pyörälä S and Pelkonen S (2015). Performance of a real-time PCR assay in routine bovine mastitis diagnostics compared with in-depth conventional culture. Journal of Dairy Research 82: 200-208.

Kassa F, Ayano AA, Abera M and Kiros A (2014). Longitudinal study of bovine mastitis in Hawassa and Wendo Genet small holder dairy farms. Global Journal of Science Frontier Research: D Agriculture and Veterinary 14: 34-41.

Kato H, Yoshida A, Ansai T, Watari H, Notomi T and Takehara T (2007). Loopmediated isothermal amplification method for the rapid detection of Enterococcus faecalis in infected root canals. Oral Microbiology and Immunology 22: 131-135.

Koskinen MT, Holopainen J, Pyorala S, Bredbacka P, Pitkala A, Barkema HW, Bexiga R, Roberson J, Solverod L, Piccinini R, Kelton D, Lehmusto H, Niskala S and Salmikivi L (2009). Analytical specificity and sensitivity of a real-time polymerase chain reaction assay for identification of bovine mastitis pathogens. Journal of Dairy Science 92: 952-959.

Krukowski H, Lisowski A, Nowakowicz-Dębek B and Wlazło $Ł$ (2013). Susceptibility of Prototheca zopfii strains isolated from cows with mastitis to chlorhexidine and iodine. Turkish Journal of Veterinary and Animal Sciences 37: 106-108. 
Lacto Data (2015). A milk SA publication compiled by the Milk Producer's Organization. 18: 1 .

Lakew M and Tolosa T, Tigre W (2009). Prevalence and major bacterial causes of bovine mastitis in Asella, South Eastern Ethiopia. Tropical Animal Health and Production 41: 1525-1530.

Mahmmod $Y$ (2013). The future of PCR technologies in diagnosis of bovine mastitis pathogens. Advances in Dairy Research 2: e106.

Man'ombe E (2014). Economic value and genetic prediction of clinical mastitis in South African holstein cattle. Thesis, Department of Animal Sciences, Stellenbosch University. [Available online at https://scholar.sun.ac.za/]. Accessed on 20 June 2016.

Mdegela RH, Ryoba R, Karimuribo ED, Phiri EJ, Løken T, Reksen O, Mtengeti E and Urio NA (2009). Prevalence of clinical and subclinical mastitis and quality of milk in smallholder dairy farms in Tanzania. Journal of the South African Veterinary Association 80: 163-168.

Mekibib B, Furgasa M, Abunna F, Megersa B and Regassa A (2010). Bovine Mastitis: Prevalence, risk factors and major pathogens in dairy farms of Holeta Town, central Ethiopia. Veterinary World 3: 97-403.

Moges N, Asfaw Y and Belihu K (2011). A cross sectional study on the prevalence of sub clinical mastitis and associated risk factors in and aronund Gondar, Northern Ethiopia. International Journal of Animal and Veterinary Advances 3: 455-459. 
Morin DE, Petersen GC, Whitmore HL, Hungerford LL and Hinton RA (1993). Economic analysis of a mastitis monitoring and control program in four dairy herds. Journal of the American Veterinary Medical Association 202: 540-548

Mungube EO, Tenhagen BA, Regassa F, Kyule MN, Shiferaw Y, Kassa T and Baumann MPO (2005). Reduced milk production in udder quarters with subclinical mastitis and associated economic losses in crossbred dairy cows in Ethiopia. Tropical Animal Health and Production 37: 503-512.

O'Connor AM, Anderson KM, Goodell CK and Sargeant JM (2014). Conducting systematic reviews of intervention questions I: writing the review protocol, formulating the question and searching the literature. Zoonoses and Public Health 61 (suppl. 1): 28-38.

Oba M (2005). Milk loss varies with mastitis pathogen. Western Dairy Digest, Winter 2005.

Osumi T, Kishimoto $\mathrm{Y}$, Kano R, Maruyama H, Onozaki M, Makimura K, Ito T, Matsubara K and Hasegawa A (2008). Prototheca zopfii genotypes isolated from cow barns and bovine mastitis in Japan. Veterinary Microbiology 131: 419-423.

Petrovski K, Heuer C, Parkinson T and Williamson N (2009). The incidence and aetiology of clinical bovine mastitis on 14 farms in Northland, New Zealand. New Zealand Veterinary Journal 57: 109-115.

Petrovski KR, Trajcev M and Buneski G (2006). A review of the factors affecting the costs of bovine mastitis. Journal of the South African Veterinary Association 77: $52-60$. 
Petrovski KR, Williamson NB, Lopez-Villalobos N, Parkinson TJ and Tucker IG (2011). Culture results from milk samples submitted to veterinary diagnostic laboratories from August 2003 to December 2006 in New Zealand. New Zealand Veterinary Journal 59: 317-322.

Petzer I-M, Karzis J, Watermeyer JC, van der Schans TJ and van Reenen R (2009). Trends in udder health and emerging mastitogenic pathogens in South African dairy herds. Journal of the South African Veterinary Association 80: 17-22.

Pfützner H and Sachse K (1996). Mycoplasma bovis as an agent of mastitis, pneumonia, arthritis and genital disorders in cattle. Revue Scietifique et Technique Del'office Internaional Des Epizooties 15: 1477-1494.

Pieper L, Godkin A, Roesler U, Polleichtner A, Slavic D, Leslie KE and Kelton DF (2012). Herd characteristics and cow-level factors associated with Prototheca mastitis on dairy farms in Ontario, Canada. Journal of Dairy Science 95: 56355644.

Pillai S, Kunze E, Sordillo L and Jayarao B (2001). Application of differential inflammatory cell count as a tool to monitor udder health. Journal of Dairy Science 84: 1413-1420.

Plotly. Online chart maker for excel and csv data. [Available online at https://plot.ly/plot/]. Accessed on 20 June 2016.

Punyapornwithaya V, Fox LK, Hancock DD, Gay JM and Alldredge JR (2012). Time to clearance of mycoplasma mastitis: The effect of management factors including milking time hygiene and preferential culling. Canadian Veterinary Journal 53: 1119-1122. 
Ranjan R, Swarup D, Patra RC and Nandi D (2006). Bovine protothecal mastitis: a review. CAB Reviews: Perspectives in Agriculture, Veterinary Science, Nutrition and Natural Resources 1, No. 017.

Ravaomanana J, Rasambainarivo JH, Perrot A, Razafiarison O and Rakotonindra S (2004). Mastitis in dairy cows and its economic impact on smallholder production in the highland zones of Madagascar. pp. 94-95, In: Proceedings of the $11^{\text {th }}$ International Conference of the Association of Institutions for Tropical Veterinary Medicine, and the 16th Veterinary Association of Malaysia Congress 23-27 August 2004.

Ricchi M, Goretti M, Branda E, Cammi G, Garbarino CA, Turchetti B, Moroni P, Arrigoni N and Buzzini P (2010). Molecular characterization of Prototheca strains isolated from Italian dairy herds. Journal of Dairy Science 93: 46254631.

Riekerink RGMO, Barkema HW, Veenstra S, Poole DE, Dingwell RT and Keefe GP (2006). Prevalence of contagious mastitis pathogens in bulk tank milk in Prince Edward Island. Canadian Veterinary Journal 47: 567-572.

Roy JP, Francoz D and Labrecque O (2008). Mastitis in a 7-week-old calf caused by Mycoplasma bovigenitalium. Veterinary Journal 176: 403-404.

Saidi R, Khelef D and Kaidi R (2013). Subclinical mastitis in cattle in Algeria: Frequency of occurrence and bacteriological isolates. Journal of the South African Veterinary Association 84: 00-00. 
Sargeant JM and O'Connor AM (2014b). Introduction to systematic reviews in animal agriculture and veterinary medicine. Zoonoses and Public Health 61 (suppl. 1): $3-9$.

Sharma N, Rho GJ, Hong YH, Kang TY, Lee HK, Hur T.-Y., and Jeong DK (2012). Bovine mastitis: An Asian perspective. Asian Journal of Animal and Veterinary Advances 7: 454-476.

Sharma N, Singh NK and Bhadwal MS (2011). Relationship of somatic cell count and mastitis: An overview. Asian-Australasian Journal of Animal Sciences 24: 429_ 438.

Shome BR, Das Mitra S, Bhuvana M, Krithiga N, Velu D, Shome R, Isloor S, Barbuddhe SB and Rahman H (2011). Multiplex PCR assay for species identification of bovine mastitis pathogens. Journal of Applied Microbiology 111: 1349-1356.

Singh PJ and Singh KB (1994). A study of economic losses due to mastitis in India. Indian Journal of Dairy Science 47: 265-272.

Sobukawa H, Yamaguchi S, Kano R, Ito T, Suzuki K, Onozaki M, Hasegawa A and Kamata H (2012). Molecular typing of Prototheca zopfii from bovine mastitis in Japan. Journa of Dairy Science 95: 4442-4446.

Sori H, Zerihun A and Abdicho S (2005). Dairy cattle mastitis in and Around Sebeta, Ethiopia. Journal of Applied Research in Veterinary Medicine 3: 332-338.

StatSilk (2012). StatPlanet: Interactive data visualization and mapping software. http://www.statsilk.com. 
Tadesse A and Chanie M (2012). Study on the occurrence of bovine mastitis in Addis Ababa dairy farms and associated risk factors. Advances in Biological Research 6: 151-158.

Taponen S, Salmikivi L, Simojoki H, Koskinen MT and Pyörälä S (2009). Real-time polymerase chain reaction-based identification of bacteria in milk samples from bovine clinical mastitis with no growth in conventional culturing. Journal of Dairy Science 92: 2610-2617.

Tomita N, Mori Y, Kanda H and Notomi T (2008). Loop-mediated isothermal amplification (LAMP) of gene sequences and simple visual detection of products. Nature Protocols 3: 877- 882.

USAD (2010). United States of America dairy industry. IUF Dairy Industry Research. [Available online at usda.mannlib.cornell.edu]. Accessed on 20 June 2016.

Viguier C, Arora S, Gilmartin N, Welbeck N and O'Kennedy R (2009). Mastitis detection: current trends and future perspectives. Trends in Biotechnology 27: 486-493.

Wang D, Wang Y, Xiao F, Guo W, Zhang Y, Wang A and Liu Y (2015). A comparison of in-house real-time LAMP assays with a commercial assay for the detection of pathogenic bacteria. Molecules 20: 9487-9495.

Watts JL (1988). Etiological agents of bovine mastitis. Veterinary Microbiology 16: 4166.

Wawron W, Bochniarz M and Piech T (2010). Yeast mastitis in dairy cows in the middle-eastern part of Poland. Bulletin-Veterinary Institute in Pulawy 54: 201204. 
Wellenberga G, Poelb WV and Oirschot JV (2002). Viral infections and bovine mastitis: a review. Veterinary Microbiology 88: 27-45.

Williamson J, and di Menna ME (2007). Fungi isolated from bovine udders, and their possible sources. New Zealand Veterinary Journal 55: 188-190.

Yalcin C, Stott AW, Logue DN and Gunn J (1999). The economic impact of mastitiscontrol procedures used in Scottish dairy herds with high bulk-tank somatic-cell counts. Preventive Veterinary Medicine 41: 135-149.

Yohannis M and Molla W (2013). Prevalence, risk factors and major bacterial causes of bovine mastitis in and around Wolaita Sodo, Southern Ethiopia. African Journal of Microbiology Research 7: 5400-5405.

Zadoks RN, Middleton JR, McDougall S, Katholm J and Schukken YH (2011). Molecular epidemiology of mastitis pathogens of dairy cattle and comparative relevance to humans. Journal of Mammary Gland and Neoplasia 16: 357-372.

Zenebe N, Habtamu T and Endale B (2014). Study on bovine mastitis and associated risk factors in Adigrat, Northern Ethiopia. African Journal of Microbiology Research 8: 327-331.

Zeryehun T, Aya T and Bayecha R (2013). Study on prevalence, bacterial pathogens and associated risk factors of bovine mastitis in small holder dairy farms in and around Addis Ababa, Ethiopia. Journal of Animal and Plant Science 23: 50-55.

Zhang J, ZHnag GH, Yang L, Huang R, Zhang Y, Jia K, Yuan W and Li SJ (2011). Development of a loop-mediated isothermal amplification assay for the detection of Mycobacterium bovis. Veterinary Journal 187: 393-396. 